\title{
Propagation of New Chestnut Rootstocks with Improved Resistance to Phytophthora cinnamomi - New Cast Rootstocks
}

\author{
Patricia Fernandes*, Andreia Amaral, Belén Colavolpe, Daniela \\ Balonas, Maria Serra, António Pereira and Rita Lourenço Costa
}

\begin{abstract}
Nowadays there is a great demand for chestnut rootstocks with improved resistance to Phytophthora cinnamomi, the causing agent of ink disease/root rot. The majority of genotypes that are being commercialized and used in the new plantations, were selected from the breeding programs of the XX century. The climate scenarios have been changing throughout the years, therefore the selection of new genotypes, better adapted to the current conditions of soil and climate, together with an effective and expedite production system, are essential to fulfill the needs of the market on better propagation materials. The INIAV's chestnut breeding program, established in 2006, aims the improvement of resistance of chestnut to biotic stresses. By taking advantage of micropropagation, this program developed a pipeline to produce new hybrid varieties with improved resistance to $P$. cinnamomi. Micropropagation helps to overcome the recalcitrance that chestnut tissues present to traditional clonal propagation techniques. This work describes the pipeline of production of these hybrids and characterizes the plants from in vitro to ex vitro conditions. The pipeline allows the development of healthy plants capable of robust and continuous growth in ex vitro conditions. Nowadays these hybrids are being multiplied in a large scale production system, to be released to the market in the near future.
\end{abstract}

Key words: Castanea; hybrids; ink disease; micropropagation; production

*Laboratory Technician, Instituto Nacional de Investigação Agrária e Veterinária I.P., Avenida da República 2780-159 OEIRAS, Portugal.

E-mail: rita.lcosta@iniav.pt

This is an Open Access article distributed under the terms of the Creative Commons Attribution License (https://creativecommons.org/licenses/by/4.0), which permits unrestricted use, distribution, and reproduction in any medium, provided the original work is properly cited. 
Fernandes, P., et al.

Propagação de Novos Porta-Enxertos de Castanheiro com Resistência Melhorada a Phytophthora cinnamomi

Sumário. Atualmente, existe uma grande necessidade de porta-enxertos de castanheiro com resistência melhorada a Phytophthora cinnamomi, o agente causal da doença da tinta/podridão da raíz. A maioria dos genótipos comercializados e utilizados nas novas plantações foram selecionados dos programas de melhoramento do século XX. No entanto, devido às alterações climáticas tornou-se necessário a seleção de novos genótipos, melhor adaptados às condições atuais do solo e do clima, juntamente com um sistema de produção eficaz e acelerado, de forma a colmatar as necessidades do mercado com material vegetal melhorado. O programa de melhoramento de castanheiro do INIAV iniciou em 2006 e visa a melhoria da resistência desta espécie a stresses bióticos. Tendo em conta a recalcitrância dos tecidos de castanheiro a técnicas convencionais de propagação, este programa desenvolveu um sistema de propagação baseado em técnicas de micropropagação para produzir novas variedades híbridas com resistência melhorada a $P$. cinnamomi. O presente trabalho descreve este sistema de produção, caracterizando as novas variedades híbridas em todas as fases do processo, desde o in vitro até ao ex vitro. Este sistema de produção permite o desenvolvimento de plantas saudáveis e capazes de crescer vigorosamente em condições ex vitro. Atualmente, a produção destas variedades é feita em larga escala para que sejam lançadas no mercado brevemente.

Palavras-chave: Castanea; doença da tinta; micropropagação; produção

Propagation de Nouveaux Porte-Greffes de Châtaignier avec une Résistance Améliorée à Phytophthora cinnamomi

Résumé. Actuellement, il existe un grand besoin de porte-greffes de châtaignier avec une résistance améliorée à Phytophthora cinnamomi, l'agent causal de la maladie de l'encre / pourriture des racines. La plupart des génotypes commercialisés et utilisés dans les nouvelles plantations ont été sélectionnés parmi les programmes de sélection du XXe siècle. Cependant, en raison du changement climatique, il est devenu nécessaire de sélectionner de nouveaux génotypes, mieux adaptés aux conditions actuelles du sol et du climat, ainsi qu'un système de production efficace et accéléré, afin de répondre aux besoins du marché avec du matériel végétal amélioré. Le programme de sélection de châtaigniers de l'INIAV a débuté en 2006 et vise à améliorer la résistance de cette espèce aux stress biotiques. Compte tenu de la récalcitrance des tissus de châtaigniers aux techniques de multiplication conventionnelles, ce programme a développé un système de multiplication basé sur des techniques de micropropagation pour produire de nouvelles variétés hybrides avec une résistance améliorée à $P$. cinnamomi. Le présent travail décrit ce système de production, caractérisant les nouvelles variétés hybrides à toutes les étapes du processus, de l'in vitro à l'ex vitro. Ce système de production permet le développement de plantes saines, capables de croître vigoureusement dans des conditions ex vitro. Actuellement, la production de ces variétés se fait à grande échelle afin qu'elles puissent être lancées sur le marché prochainement.

Mots-clés: Castanea; hybrides; maladie de l'encre; micropropagation; production 


\section{Introduction}

The European chestnut (Castanea sativa Mill.) is a multipurpose tree, having a significant economic interest for nut and wood production. Chestnut cultivars have been maintained by clonal propagation using agronomic techniques like rooting of cuttings, however, root induction in mature chestnut tissue has proven to be a very difficult process (VIEITEZ et al., 1987; VIEITEZ, 1992). In the past century, chestnut cultivars were also propagated by grafting on seedlings of C. sativa (PEREIRA-LORENZO and FERNANDEZ-LOPEZ, 1997). Nevertheless, due to the high susceptibility of this species to the oomycete Phytophthora cinnamomi (causing agent of the root rot/ink disease) (HARDHAM, 2005), the use of this technique is now compromised.

The Japanese (Castanea crenata Siebold and Zucc.) and Chinese (Castanea mollissima Blume) chestnut species are resistant to the disease, but their nuts do not have significant commercial value and they cannot be used as rootstocks due to grafting incompatibility with C. sativa (HONGWEN et al., 1994). Taking this into consideration, hybrid clones of $C$. sativa with the Asian species have been used as rootstocks grafting for plantations in affected areas (PEREIRA-LORENZO and FERNANDEZ-LOPEZ, 1997; GONÇALVES et al., 1998).

The available genotypes in the European market are from breeding programs from the XX century (BREISCH et al., 1995; PEREIRA-LORENZO and FERNANDEZLOPEZ, 1997). However, a change was projected in the distribution of the pathogen in the next years due to climate change (BURGESS et al., 2017) which might bring up different disease expressions (due to the emergence of new strains and hosts). This creates a demand for new chestnut material, more adapted to the current climatic conditions. Therefore, new genotypes with improved resistance to P. cinnamomi were selected from the INIAV's Chestnut Breeding Program initiated in 2006 (COSTA et al., 2011; SANTOS et al., 2015, 2016).

Micropropagation has great potential as it produces healthy plant materials with robust root systems that contribute to a better adaptation in field conditions. This technology has also the potential of accelerating the delivery of plant material to the nurseries, has it is more efficient than traditional propagation methods because it can produce plants throughout the year. Several micropropagation protocols have been developed for chestnut (SEABRA and PAIS, 1993; SÁNCHEZ et al., 1997; GIOVANNELLI and GIANNINI, 2000; BALLESTER et al., 2001; TETSUMURA and YAMASHITA, 2004; OAKES et al., 2016). Taking this into consideration, the in vitro propagation system was implemented 
Fernandes, P., et al.

to propagate the new improved genotypes, selected from the INIAV's Chestnut Breeding Program, having a large scale production perspective to fulfill the needs of the market on better propagation materials.

The goal of this work was to describe the propagation method of the new Euro-Asian chestnut hybrids from the laboratory to the field. The in vitro development of three selected genotypes was characterized by multiplication rates and morphology in the steps prior to rooting. The root induction, development in greenhouse and development on the field were also evaluated.

\section{Materials and methods}

\section{Plant material}

The three chestnut hybrid genotypes used for these experiments were obtained from controlled crosses and selected for their resistance to $P$. cinnamomi, after inoculation with the pathogen (COSTA et al., 2011, SANTOS et al., 2015), namely: variety SM904, hybrid between C. sativa x C. mollissima and varieties SC1202 and SC55, C. sativa $\times$ C. crenata hybrids.

\section{Culture conditions and shoot propagation}

In vitro multiplication was carried out as described in SANTOS et al., (2017). Shoots were placed in Murashige and Skoog (MS) medium (MURASHIGE and SKOOG, 1962) (half concentration of $\mathrm{NH}_{4} \mathrm{NO}_{3}$ and $\mathrm{KNO}_{3}$ ), supplemented with 0.1 $\mathrm{mg} / 1$ benzyladenine (BA), $30 \mathrm{~g} / 1$ sucrose and $8 \mathrm{~g} / 1$ agar. Fifteen shoots were placed per vessel (Eco2Box with green filter; oval model $80 \mathrm{~mm} \mathrm{H}$; Duchefa biochemie) and cultures were maintained at $23^{\circ} \mathrm{C}$ under a 16 hour light photoperiod.

The multiplication rate of each genotype was obtained by counting the number of new shoots rising from the basis of the initial shoot, by the end of the subculture period (corresponding to 6 weeks). Seventy-five biological replicates were analyzed per subculture during 3 subcultures. 
Elongation procedure and morphological characterization

Six-week-old shoots were transferred to full-strength Woody Plant Medium (WPM) (LLOYD and MCCOWN, 1980), $30 \mathrm{~g} / 1$ sucrose and supplemented with 0,1 $\mathrm{mg} / 1$ of zeatin and $8 \mathrm{~g} / \mathrm{L}$ agar. The $\mathrm{pH}$ was adjusted to 5,6-5,8 before autoclaving at $121^{\circ} \mathrm{C}$ and 15 psi for 20 minutes. The containers and culture conditions were the same as described in the previous section.

The development of six-week-old shoots micropropagated in elongation media was morphologically characterized by measuring the length of the biggest shoot length $(\mathrm{mm})$, the number of leaves per shoot, biggest leaf length and width $(\mathrm{mm})$, dry mass $(\mathrm{mg})$ (after drying at $60^{\circ} \mathrm{C}$ over night), moisture (\%) (calculated by using the formula $\frac{\text { Fresh weight }}{\text { Dryweight }} \times 100$ ) and stem diameter $(\mathrm{mm})$. Forty-five biological replicates were analyzed.

\section{Rooting process}

Prior to rooting, elongated shoots were subcultured on a pre-rooting medium composed by MS medium described above (without plant growth regulators) plus $3 \mathrm{~g} / \mathrm{L}$ charcoal for 7-10 days (SANTOS et al., 2017) for cytokinin detoxification. Shoots were removed from the elongation medium, excised from the callus mass and placed into the new vessels for 7 days. The surface of the cut ends was then renewed by cutting 1-2mm under tap water. After this procedure shoots were dipped in a $2 \mathrm{~g} / 1$ indole-3-butyric acid (IBA) aqueous solution, at a depth of $0.5 \mathrm{~cm}$ for 1 minute and placed in paperpots (previously soaked with tap water) for root development. Nine paper pots were set in closed clear plastic boxes (SteriVent Containers; High model; Duchefa biochemie) in greenhouse tunnels at $25^{\circ} \mathrm{C}$ with a relative humidity of $95 \%$ (controlled by humidity probes) under natural light. The number of shoots used for rooting assays was 405, 87 and 89 for SM904, SC1202, and SC55, respectively. After 3 weeks the number of rooted shoots was registered and presented as mean values.

\section{Acclimatization and ex vitro development}

Rooted plants were transferred to peat: perlite $(7: 3)$ mixture (300ml pots) and placed in an acclimatization clear tunnel at $25^{\circ} \mathrm{C}$ under a natural photoperiod. Relative humidity levels started at $90 \%$ and gradually decreased to $60 \%$ for 7 
Fernandes, P., et al.

days. After this period, plants were transferred to the greenhouse and maintained at proximally $23^{\circ} \mathrm{C}$. Sprinkle fertigation was done once a week for 10 min. The fertilizer consisted of a 1:1 solution of GREEN LB (16 g/l) and YELLOW $(16 \mathrm{~g} / \mathrm{l})$ from YaraTera KRISTALON, with an Electric Conductivity (EC) of 1.00. The height of 10 plants of each genotype was registered for 2 months and presented as mean values and Standard Error (SE) of the mean.

Plants were transferred to field conditions (GPS coordinates: 39.347494, 7.395609; field with sandy soil; $\mathrm{pH}=4.9$ ) with a spacing of $7 \times 7 \mathrm{~m}$. The height of 6 trees of each genotype was registered every 6 months during 2 years to estimate the annual growth rate.

\section{Statistical analysis}

The multiplication rates were analyzed and presented as means and SE for each subculture. An analysis of variance (Kruskal-Wallis test) was performed to check for differences throughout subcultures in each genotype. Differences between genotypes multiplication were also analyzed with the same test by considering all data collected from the 3 subcultures (all 225 biological replicates per genotype). Significantly different means were identified by using the Dunn's Multiple Comparison Test $(\mathrm{P}<0.05)$. Data were listed as mean values and SE.

Elongation data were analyzed and presented as means and SE. The genotypes were compared for each growth parameter by performing an analysis of variance for the different parameters of growth (Kruskal-Wallis test). Significantly different means were identified by using the Dunn's Multiple Comparison Test $(\mathrm{P}<0.05)$.

All tests were performed using GraphPad Prism version 5.00 for Windows, GraphPad Software, San Diego California USA, www.graphpad.com.

\section{Results and discussion}

In this work, we describe in vitro and ex vitro development of 3 new chestnut hybrid varieties resistant to $P$. cinnamomi. This production pipeline enables chestnuts development from the laboratory to the orchard. The mass production of these genotypes aims to disclose to the market new rootstocks with improved resistance to root rot/ ink disease.

The multiplication rates for the 3 genotypes are presented in Figure 1. These data revealed significant differences among genotypes $(p=0.0003)$ with the 
highest multiplication rate presented by SM904 with 2.573 new shoots. Followed by SC55 and SC1202 with 2.253 and 2.053 new shoots, respectively. These rates are in accordance with the ones described for Euro-Asian hybrids, namely from 2,5 to 3 new shoots/explant (BALLESTER et al., 2001; MIRANDA and FERNANDEZ, 2001). However, the previous works used MS medium supplemented with $0.2 \mathrm{mg} / 1 \mathrm{BA}$, double the concentration used in the present work.

SM904 revealed to be the genotype with the best consistency throughout the repeated subcultures with no significant differences between them (Figure 2). Unlike SC55 $(\mathrm{p}=0.0176)$ and SC1202 $(\mathrm{p}=0.0169)$ which present a significant decrease in the number of shoots in the last subculture (Figure 2).

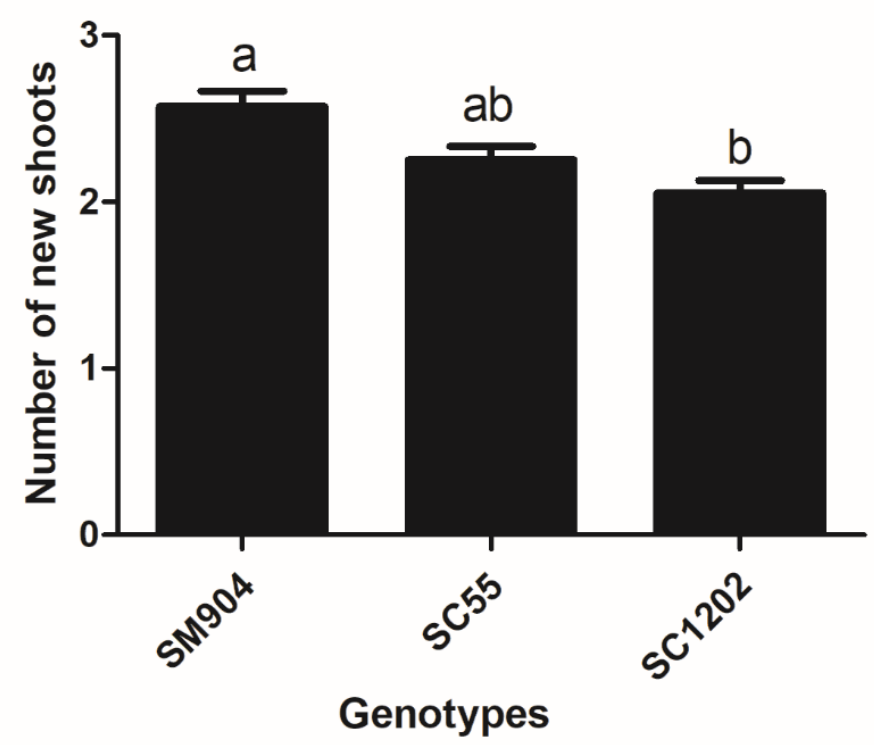

Figure 1 - Multiplication of hybrid chestnuts after 6 weeks in culture in MS medium supplemented with $0.1 \mathrm{mg} / \mathrm{L}$ BA. The values are means \pm standard error corresponding to 3 different subcultures $(n=225)$. Different superscript letters indicate significant differences between genotypes at $\mathrm{p}<0.05$, according to Dunn's Multiple Comparison Test 


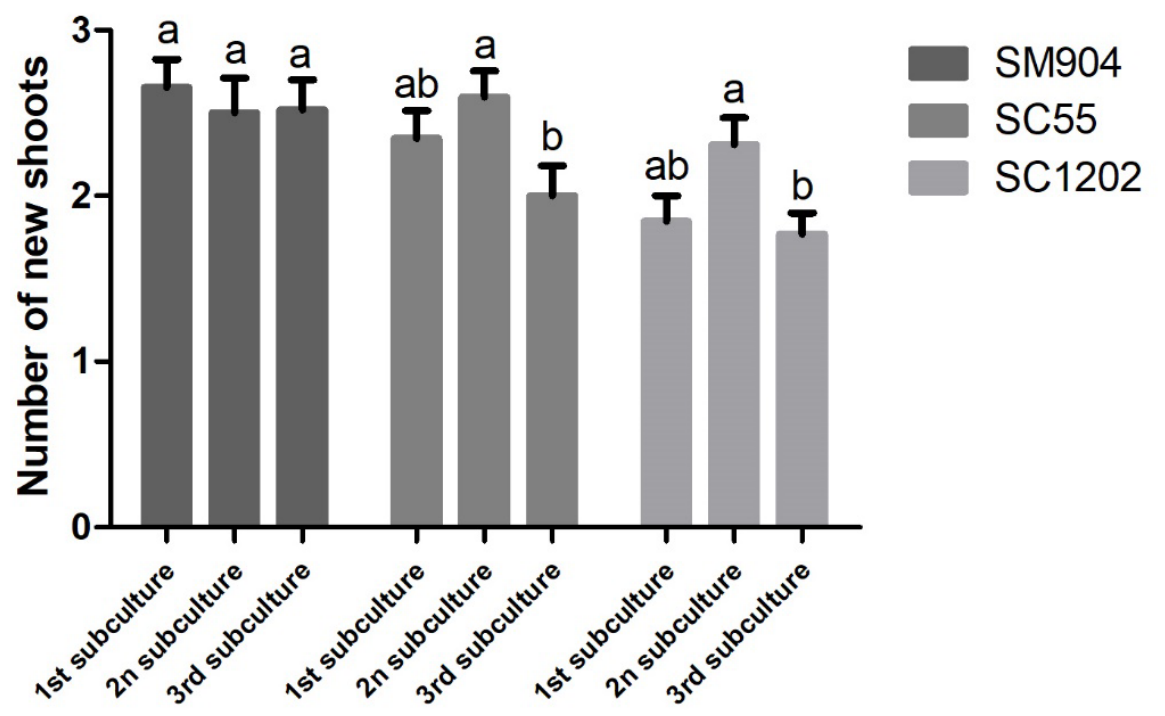

Figure 2 - Effect of repeated subcultures on the multiplication of hybrid chestnuts micropropagated in MS medium supplemented with $0.1 \mathrm{mg} / \mathrm{L}$ BA. The values are means \pm standard error $(n=75)$. Within genotype subcultures, different superscript letters indicate significant differences at $\mathrm{p}<0.05$, according to Dunn's Multiple Comparison Test

The elongation phase was carried out using zeatin, a plant growth regulator that has been previously described as the best for in vitro culture in Castanea species by giving the best results in terms of shoot length, number of leaves and also multiplication rate when compared to BA and Thidiazuron (TETSUMURA and YAMASHITA, 2004).

The characterization of several morphological parameters, of the chestnut hybrids, after 6 weeks of elongation is presented in Figure 3. All the genotypes presented distinct in vitro phenotypes. SM904 is characterized by having long shoots, with the smallest leaves, less dry mass and higher moisture content. SC55 shoots were the shortest and with less number of leaves. SC1202 stood out by having higher dry mass content. 

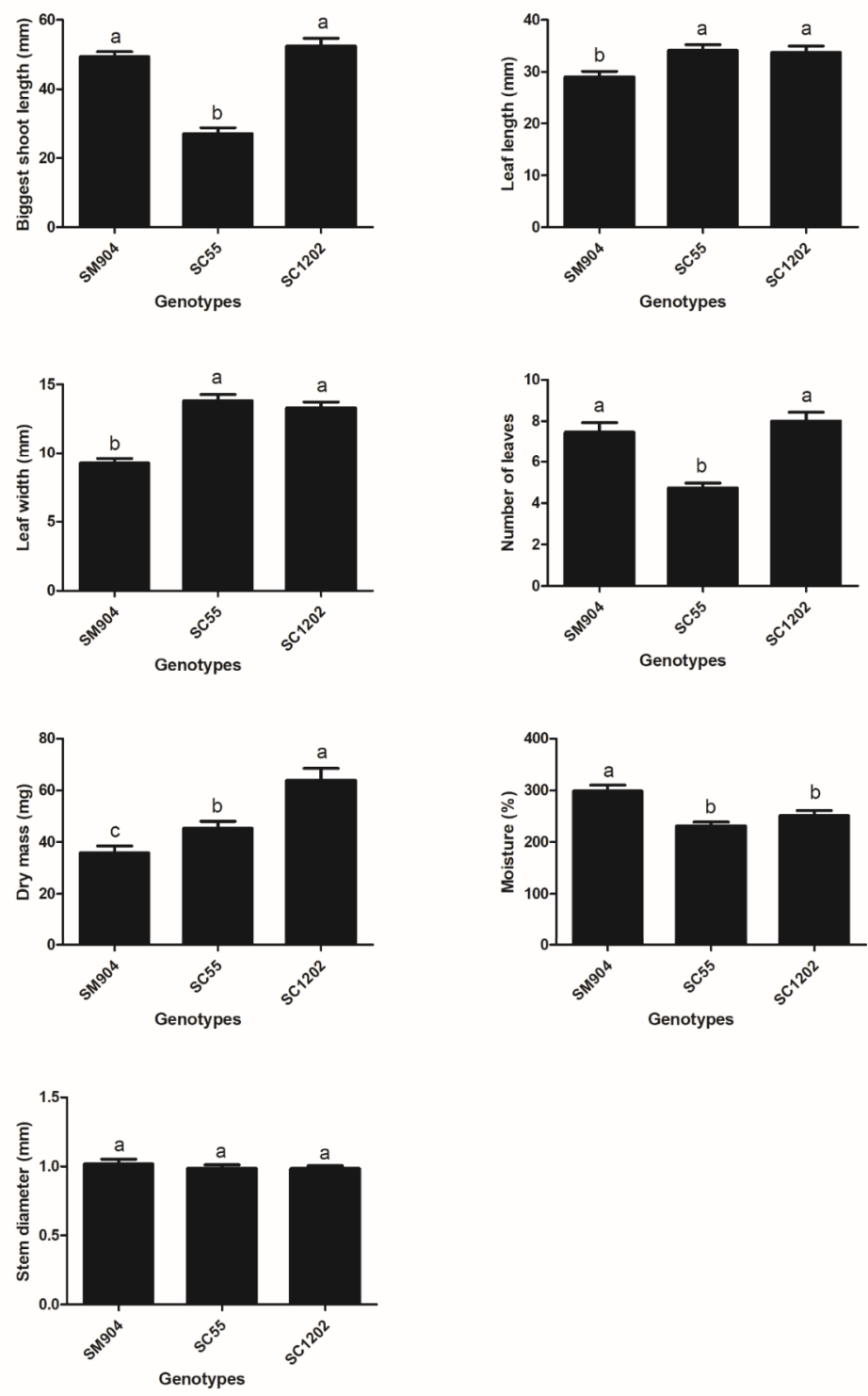

Figure 3 - Effects of a 6-week elongation subculture in WPM medium supplemented with $0.1 \mathrm{mg} / 1$ zeatin on biggest shoot length $(\mathrm{mm})$, leaf length and width $(\mathrm{mm})$, number of leaves, dry mass $(\mathrm{mg})$, moisture $(\%)\left(\frac{\text { Fresh weight }}{\text { Dryweight }} \times\right.$ 100) and stem diameter (mm), in SM904, SC55, and SC1202 genotypes. Data are presented as means \pm standard error $(n=45)$. Different superscript letters indicate significant differences at $\mathrm{p}<0.05$, according to Dunn's Multiple Comparison Test 
Three weeks after induction with $2 \mathrm{~g} / \mathrm{L}$ IBA, it was possible to observe root development in all genotypes (Figure 4). SM904 rooted 315 out of 405 shoots (77.7\%), SC55 69 out of 89 (77.5\%) and SC1202 48 out of 87 (55.2\%). Similar rooting percentages have been described for other Castanea species (XING et al., 1997; TETSUMURA and YAMASHITA, 2004; OAKES et al., 2015).

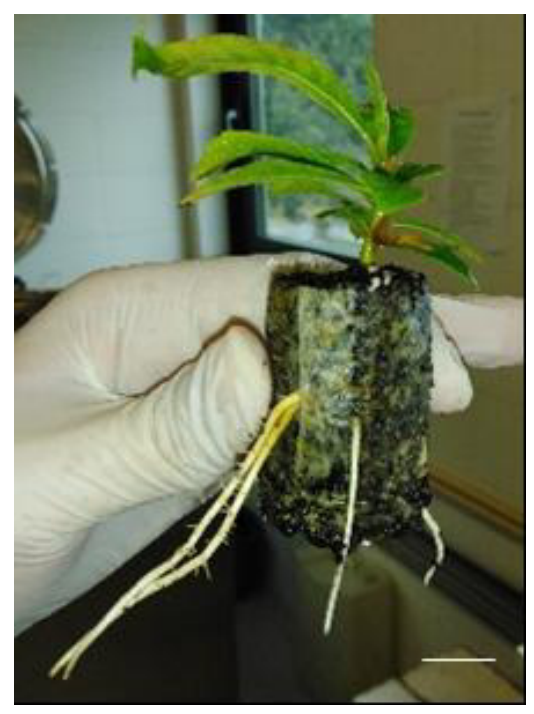

Figure 4 - SM904 rooted shoot in paperpot. Root development 3 weeks after 2 $\mathrm{g} / 1$ IBA hormonal shock. The bar corresponds to $1 \mathrm{~cm}$

The development of plant height for the 2 months in the greenhouse after acclimatization is shown in Table 1 and Figure 5. The plants' initial height was similar for the 3 genotypes $(2.4 \mathrm{~cm}$ average). After 2 months of development, SM904 presented the highest values with $9.4 \mathrm{~cm}$, in comparison with SC55 and SC1202 with $6.15 \mathrm{~cm}$ and $7.05 \mathrm{~cm}$, respectively.

Table 1 - Height development of SM904, SC55, and SC1202 after acclimatization and with 1 month and 2 months in the greenhouse. $n=10 ; \bar{X}$ - means; SE Standard Error

\begin{tabular}{|c|c|c|c|c|c|c|}
\hline \multirow{2}{*}{ Genotype } & \multicolumn{2}{|c|}{ After Acclimatization } & \multicolumn{2}{c|}{ 1 Month } & \multicolumn{2}{c|}{ 2 Months } \\
\cline { 2 - 7 } & $\overline{\mathrm{X}}$ & SE & $\overline{\mathrm{X}}$ & SE & $\overline{\mathrm{X}}$ & SE \\
\hline SM904 & 2.3 & 0.6 & 4.05 & 0.75 & 9.4 & 2.7 \\
\hline SC55 & 2.6 & 0.34 & 4.35 & 0.88 & 6.15 & 1.68 \\
\hline SC1202 & 2.2 & 0.74 & 3.85 & 1.02 & 7.05 & 2.35 \\
\hline
\end{tabular}




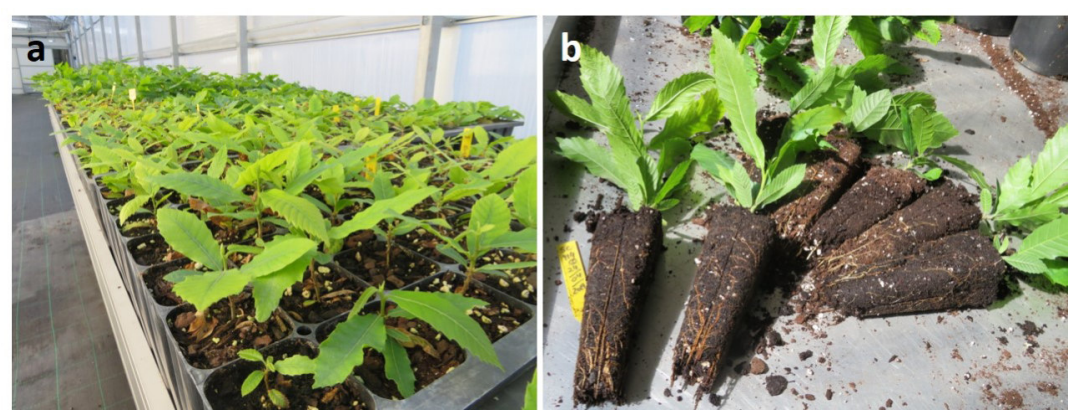

Figure 5 - SM904 plants with 1 month (a) and 2 months (b) of development in the greenhouse

In the field, the plantation success obtained for the three genotypes was $90 \%$. After 2 years of development on the field (Figure 6), the estimated annual growth rates for each genotype were $9.5 \%, 11.9 \%$ and $2.8 \%$ for SC55, SC1202, and SM904 respectively.

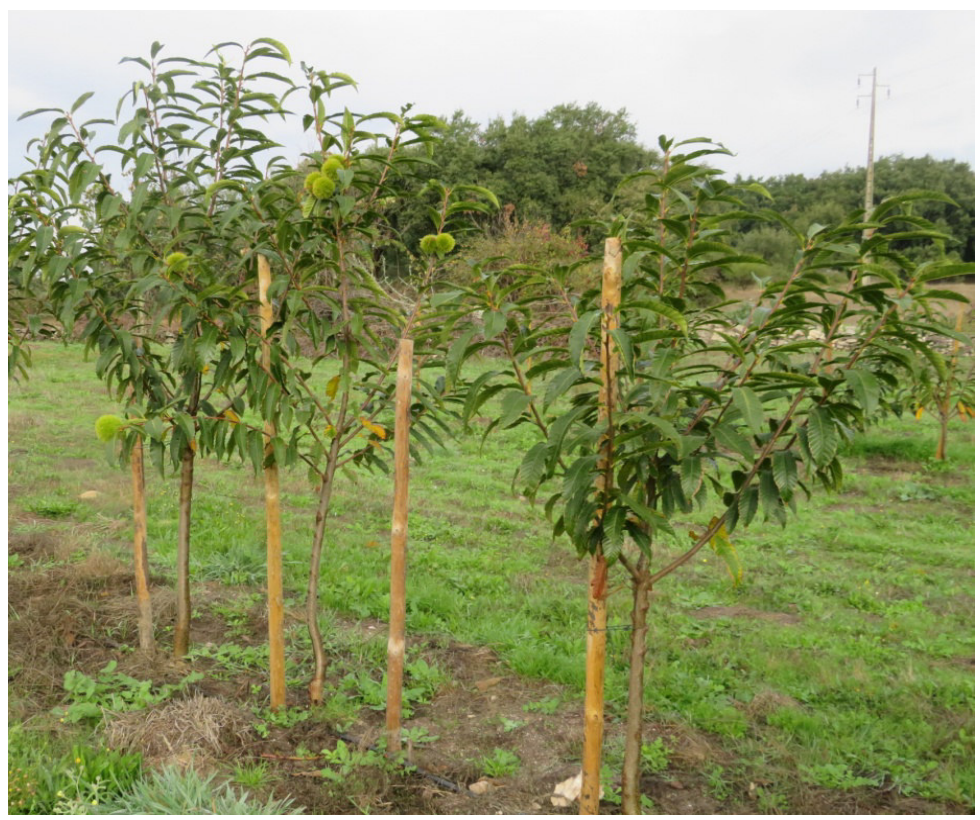

Figure 6 - Hybrid chestnuts in the field, 2 years after plantation 
In this work, it was possible to identify different characteristics and behavior in vitro and ex vitro culture. Globally SM904 is the best genotype in vitro, in terms of rooting rates and greenhouse growth. However, in the field, it is the one that shows the lowest annual field growth. Also, SC1202 seems to have disadvantages in vitro when comparing to the other two genotypes. Nevertheless, it has a high field growth.

Nowadays, the Portuguese Breeding Program has several ongoing experiments to better characterize the development of these rootstocks on the field. The growth in height is still being monitored for more accurate data. Irrigation tests have been also established. Initial data suggest that plant growth is improved in plants irrigated with 4 and 8 liters of water per hour. Eight months after plantation some plants were able to be grafted with $C$. sativa fruit varieties (Martaínha, Longal, Bária and Judia). Thirty rootstocks were grafted with a success rate of $92 \%$.

Table 2 - General description of Euro-Asian hybrid rootstocks at in vitro and ex vitro stages of the production pipeline

\begin{tabular}{|c|c|l|c|c|c|}
\hline \multirow{2}{*}{ Genotypes } & \multicolumn{3}{|c|}{ In Vitro } & \multicolumn{2}{c|}{ Ex vitro } \\
\cline { 2 - 6 } & $\begin{array}{c}\text { Multiplication } \\
\text { Rate }\end{array}$ & $\begin{array}{l}\text { Elongated Shoots' } \\
\text { Phenotype }\end{array}$ & $\begin{array}{c}\text { Rooting } \\
\text { Rate }\end{array}$ & $\begin{array}{c}\text { Greenhouse } \\
\text { Growth }\end{array}$ & $\begin{array}{c}\text { Annual Field } \\
\text { Growth }\end{array}$ \\
\hline SM904 & Highest & $\begin{array}{l}\text {-Long shoots } \\
\text {-Small leaves } \\
\text {-Low dry mass } \\
\text {-High moisture }\end{array}$ & High & Highest & \\
\hline SC55 & Intermediate & $\begin{array}{l}\text {-Short shoots } \\
\text {-Low number } \\
\text { of leaves }\end{array}$ & High & Lowest & \\
\hline SC1202 & Lowest & $\begin{array}{l}\text {-Long shoots } \\
\text {-High dry mass }\end{array}$ & Mediocre & Intermediate & High \\
\hline
\end{tabular}

These preliminary data suggest that all genotypes, used as rootstocks, present high compatibility with the main varieties used in Portugal for nut production. The scion growth was on average of $1 \mathrm{~m}$ after 1 year of grafting. However, graft unions can break after years of growing (PINA et al., 2009), hence complete graft compatibility is not yet proved.

The key factors of the new hybrid varieties propagation pipeline include 1) the production of whole plants with both vigorous aerial and radicular systems; 
2) a practical strategy that reduces the propagation time when compared to traditional methods of chestnut propagation, and 3) an easily applied method for the production of Castanea hybrids for the agro biotechnological industry.

In conclusion, despite all the difficulties inherent to the production process, the breeding program benefits from a reliable tissue culture protocol that enables to manage a large scale vegetative propagation of elite genotypes. Nowadays, all the selected genotypes with improved resistance to P. cinnamomi, are being produced by this method and market release is expected in the near future.

\section{Acknowledgments}

This work was supported by Programa ProDer, Medida 4.1 Ref 53593 !Innovation in the production chain of chestnut: competitiveness and sustainability" and Projeto ALT20-03-0246-FEDER-000011 - NEW Cast Rootstocks from Programa Alentejo 2020.

\section{References}

BALLESTER, A., BOURRAIN, L., CORREDOIRA, E., GONÇALVES, J.C., LÊ, C.-L., MIRANDAFONTAÍNÁ, E., et al., 2001. Improving chestnut micropropagation through axillary shoot development and somatic embryogenesis. For. Snow Landsc. Res. 76: 460-467.

BREISCH, H., BOUTITIE, A., REYNE, J., SALESSES, G., VAYSSE, P., 1995. Châtaignes et marrons. Paris: FRA : CTIFL Centre Technique des Fruits et Légumes.

BURGESS, T.I., SCOTT, J.K., MCDOUGALL, K.L., STUKELY, M.J.C., CRANE, C., DUNSTAN, W.A., et al., 2017. Current and projected global distribution of Phytophthora cinnamomi, one of the world's worst plant pathogens. Glob. Chang. Biol. 23: 1661-1674. doi:10.1111/gcb.13492.

COSTA, R., SANTOS, C., TAVARES, F., MACHADO, H., GOMES-LARANJO, J., KUBISIAK, T., et al., 2011. Mapping and transcriptomic approches implemented for understanding disease resistance to Phytophthora cinammomi in Castanea sp. BMC Proc. 5, O18. doi:10.1186/1753-6561-5-S7-O18.

GIOVANNELLI, A., GIANNINI, R., 2000. Reinvigoration of mature chestnut (Castanea sativa) by repeated graftings and micropropagation. Tree Physiol. 20: 1243-1248.

GONÇALVES, J. C., DIOGO, G., AMÂNCIO, S., 1998. In vitro propagation of chestnut (Castanea sativa $\times$ C . crenata): Effects of rooting treatments on plant survival, peroxidase activity and anatomical changes during adventitious root formation. Sci. Hortic. (Amsterdam). 72: 265-275. 
Fernandes, P., et al.

HARDHAM, A.R., 2005. Phytophthora cinnamomi. Mol. Plant Pathol. 6: 589-604. doi:10.1111/ J.1364-3703.2005.00308.X.

HONGWEN, H., NORTON, J.D., BOYHAN, G.E., ABRAHAMS, B.R., 1994. Graft compatibility among chestnut (Castanea) species. doi:10.21273/jashs.119.6.1127.

LLOYD, G., MCCOWN, B., 1980. Commercially feasible micropropagation of mountain laurel, (Kalmia latifolia) by use of shoot tip culture. Comb. Proc. Int. Plant Propagators' Soc. 30: 421-427.

MIRANDA, M., FERNANDEZ, J., 2001. Genotypic and Environmental Variation of Castanea crenata $\times$ C. sativa and Castanea sativa Clones in Aptitude to Micropropagation. Silvae Genet. 50: 153-162.

MURASHIGE, T., SKOOG, F., 1962. A Revised Medium for Rapid Growth and Bio Assays with Tobacco Tissue Cultures. Physiol. Plant. 15: 473-497. doi:10.1111/j.13993054.1962.tb08052.x

OAKES, A.D., POWELL, W.A., MAYNARD, C.A., 2015. Improving rooting and acclimatization of micropropagated transgenic American chestnut. 2015.

OAKES, A., DESMARAIS, T., POWELL, W.A., MAYNARD, C.A., 2016. Improving Rooting and Shoot Tip Survival of Micropropagated Transgenic American Chestnut Shoots. HortScience 51: 171-176.

PEREIRA-LORENZO, S., FERNANDEZ-LOPEZ, J., 1997. Propagation of chestnut cultivars by grafting: Methods, rootstocks and plant quality. J. Hortic. Sci. 72: 731-739. doi:10.1080/14620316.1997.11515565.

PINA, A.N.A., ERREA, P., SCHULZ, A., MARTENS, H.J., 2009. Cell-to-cell transport through plasmodesmata in tree callus cultures. Tree Physiol. 29: 809-818. doi:10.1093/ treephys/tpp025.

SÁNCHEZ, M., BALLESTER, A., VIEITEZ, A., 1997. Reinvigoration treatments for the micropropagation of mature chestnut trees. Ann. des Sci. For. 54: 359-370. doi:10.1051/ forest:19970404.

SANTOS, C., DUARTE, S., TEDESCO, S., FEVEREIRO, P., COSTA, R.L., 2017. Expression Profiling of Castanea Genes during Resistant and Susceptible Interactions with the Oomycete Pathogen Phytophthora cinnamomi Reveal Possible Mechanisms of Immunity. Front. Plant Sci. 8: 515. doi:10.3389/fpls.2017.00515.

SANTOS, C., MACHADO, H., CORREIA, I., GOMES, F., GOMES-LARANJO, J., COSTA, R., 2015. Phenotyping Castanea hybrids for Phytophthora cinnamomi resistance. Plant Pathol. 64: 901-910. doi:10.1111/ppa.12313.

SANTOS, C., MACHADO, H., SERRAZINA, S., GOMES, F., GOMES-LARANJO, J., CORREIA, I., et al., 2016. Comprehension of resistance to diseases in chestnut. Rev. Ciências Agrárias 39: 189-193. doi:10.19084/RCA15145.

SEABRA, R.C., PAIS, M.S., 1993. Micropropagação de Clones de Castanheiro (Castanea sativa Mill.) Resistentes à doença da tinta. Silva Lusitana 1: 169-181. 
TETSUMURA, T., YAMASHITA, K., 2004. Micropropagation of Japanese Chestnut ( Castanea crenata Sieb . et Zucc .) Seedlings. HortScience 39: 1684-1687.

VIEITEZ, E., 1992. The Lack of Rootability of Chestnut Cuttings. in Proceedings International Chestnut Conference, eds. M.L. Double and W.L. MacDonald (West Virginia University Press: Morgantown, WV, USA), pp. 82-88. Available at: https://npn.rngr.net/ publications/chestnut/1992/the-lack-of-rootability-of-chestnut-cuttings.

VIEITEZ, J., KINGSTON, D.G., BALLESTER, A., VIEITEZ, E., 1987. Identification of two compounds correlated with lack of rooting capacity of chestnut cuttings. Tree Physiol. 3: 247-55. doi:10.1093/TREEPHYS/3.3.247.

XING, Z., SATCHWELL, M.F., POWELL, W.A., MAYNARD, C.A., 1997. Micropropagation of american chestnut: increasing rooting rate and preventing shoot - tip necrosis. Vitr. Cell. Dev. Biol.-Plant 33: 43-48. 